\title{
PRELIMINARY SCREENING OF PHYTOCHEMICAL CONSTITUENTS, ANTIOXIDANT AND ANTIMICROBICIDAL ACTIVITIES IN THE METHANOLIC LEAF EXTRACT OF COUROUPITA GUIANENSIS
}

\author{
SUJATHA ILANGOVAN*, THAVASUMANI P \\ Department of Zoology, Holy Cross College (Autonomous), Tiruchirappalli, Tamil Nadu, India. Email: sujathailangovan@hcctrichy.ac.in \\ Received: 05 October 2020, Revised and Accepted: 04 December 2020
}

\section{ABSTRACT}

Objective: The objective of the study was the preliminary screening of the methanolic leaf extract of Couroupita guianensis for various phytochemical constituents, its antioxidant, antibacterial, and antifungal activities.

Methods: Phytochemical screening of 18 qualitative, 6 quantitative constituents, antioxidant activity, alpha-amylase inhibitory activity, and alphaglucosidase inhibitory activity of the methanolic extract of the leaf of $C$. guianensis was performed adopting the standard protocols. The disk diffusion methods were used for assessing the antibacterial and antifungal activities of the extract.

Results: The preliminary studies revealed the presence of alkaloids, saponin, flavonoids, phenol, tannin, and terpenoids in the methanolic extract of the leaf of $C$. guianensis. Potent antioxidant, free radical scavenging activity, and inhibitory activity against $\alpha$-amylase and $\alpha$-glucosidase activity of the methanolic extract were also evident.

Conclusions: The preliminary studies in the methanolic extract of the leaf of C. guianensis are suggestive of the therapeutic potentials of the methanolic extract of leaves of C. guianensis.

Keywords: C.guianesis, methanolic extract, antioxidant, antimicrobicidal

(c) 2021 The Authors. Published by Innovare Academic Sciences Pvt Ltd. This is an open access article under the CC BY license (http://creativecommons.org/ licenses/by/4.0/) DOI: http://dx.doi.org/10.22159/ajpcr.2021v14i1.39923. Journal homepage: https://innovareacademics.in/journals/index.php/ajpcr

\section{INTRODUCTION}

Diabetic mellitus is a chronic metabolic disorder reported to be one of the leading causes of death. $90-95 \%$ of diabetes is of type 2 diabetes mellitus, a heterogeneous disorder due to insulin resistance or due to faulty insulin secretion [1]. Survey of literature reveals an ocean of information on the medications available for the treatment of diabetes, namely, anti-diabetic drugs and as well as human/pork/beef insulin all of which decrease blood glucose level [2,3]. On the other hand, serious side effects such as gastrointestinal flatulence, diarrhea, and abdominal pain caused by these anti-diabetic drugs cannot be ignored [4]. Hence, the need for an alternate natural remedy for diabetes is the need of the hour. WHO has reported more than 21,000 plants used for medicinal purposes, of which about 300 plants used for the treatment of diabetes [3].

A number of authors have documented the anti-inflammatory, antihelminthic, and antioxidant activity of parts of Couroupita guianensis such as leaf, fruit, and root. They have affirmed the presence of many phytochemical compounds such as ketosteroids, oils, courouptine, and indirubin [5-7]. A preliminary screening of phytochemical constituents, antioxidant, antibacterial, and antifungal activities in the methanolic leaf extract of $C$. guianensis was undertaken in this research work.

\section{MATERIALS AND METHODS}

\section{Collection of Plant Material}

Leaves of $C$. guianensis were collected in the month of November from Kavandampatti at Karur district in Tamil Nadu, India. The plant authentication (PT 001) was confirmed by Rapinat herbarium at St. Joseph College, Tiruchirappalli, Tamil Nadu.

\section{Preparation of Extract}

C. guianensis leaves were washed in running tap water, cut into small pieces, shade dried for a week, thence grinded to form a uniform- sized powder, and sieved in mesh size 30 . One hundred grams of the dried powder were soaked in 1 liter of methanol for $10 \mathrm{~h}$ in a Soxhlet extractor. The extract was filtered using Whatman filter paper, added DMSO, and used for further analysis.

\section{Phytochemical Screening}

Standard procedures were used for the screening of phytochemical constituents from the methanolic leaf extracts of C. guianensis [8-10]. Eighteen phytochemical constituents were screened qualitatively, namely, tannins, phlobatannins, saponins, flavonoids, steroids, terpenoids, cardiac glycosides, anthocyanins, leucoanthocyanin, emodin, anthraquinone, proteins, coumarins, phenols, glycosides, alkaloids, xanthoproteins, and carbohydrates.

Six phytochemical constituents, namely, flavonoid, tannin, saponin, alkaloid, phenol, and terpenoids, were assessed quantitatively.

\section{Antioxidant Activity}

The ability of the methanolic leaf extracts of C. guianensis to scavenge the free radical DDPH was determined to assess the antioxidant activity as adopted by Braca et al. [11].

Alpha Amylase and Alpha-glucosidase Inhibitory Activity The alpha-amylase inhibitory activity of the methanolic leaf extracts of $C$. guianensis was estimated using a modified procedure adopted by McCue and Shetty [12]. The alpha-glucosidase activity was computed adopting the method described by Kim et al. [13].

\section{Antimicrobicidal Activity}

Disk diffusion method was used to determine the antibacterial and antifungal activities of crude methanolic leaf extracts of $C$. guianensis. Mueller-Hinton agar was used for the bacterial culture and Sabouraud's dextrose agar was used for the culture of fungal organisms. Sterile disk 
of $6 \mathrm{~mm}$ width was used for preparing different concentrations of crude methanolic leaf extracts of $C$. guianensis. The Petri plates were inoculated with the test organisms, disks implanted and incubated. The zone of inhibition was measured around each well after $24 \mathrm{~h}$ at $37^{\circ} \mathrm{C}$. Disk impregnated in DMSO was used as control.

\section{Statistical Analysis}

SPSS Windows Students version software was used to analyze the results of the quantitative data, which is expressed as mean \pm standard deviation (SD).

\section{RESULTS AND DISCUSSION}

Phytochemical Screening

Qualitative assay for the various phytochemical compounds revealed the presence of 14 constituents, namely, tannins, saponins, flavonoids, steroids, terpenoids, leucoanthocyanin, anthocyanin, coumarins, glycosides, phenol, alkaloids, xanthoproteins, emodin, and carbohydrates (Table 1). On the other hand, compounds such as cardiac glycosides, phlobatannins, anthraquinone, and proteins were not reported in our experiments. A number of researchers have also reported the presence of a wide range of one or more of these compounds in solvent extracts from different parts of Stevia rebaudiana [14]; Gymnema montanum [15]; aqueous root bark extract of Blighia sapida [16]; and in leaves of C. guianensis [17]. Anticancer potentials in the polysaccharides isolated from the methanolic extract of Tinospora cordifolia stem bark has also been established [18]. Furthermore, many authors have also affirmed the presence of many phytochemical compounds such as ketosteroids, oils, courouptine, and indirubin in various parts of $C$. guianensis $[5,7,19]$ Thus, presence of the various phytochemical compounds in $C$. guianensis can thus be validated.

The amount of flavonoid, tannin, saponin, alkaloid, phenol, and terpenoid estimated from the methanolic extracts of leaves of C. guinanesis is presented in Table 2. Least concentration of $1.1 \pm$ $0.06 \times 10^{2} \mathrm{mg} / 100 \mathrm{~g}$ of phenol and a maximum quantity of flavonoid with $30.4 \pm 1.52 \times 10^{2} \mathrm{mg} / \mathrm{g}$ was evident. The quantity of terpenoids, alkaloids, tannins, and saponins were found to show an ascending trend with $1.7 \pm 0.09 \times 10^{2}, 2.4 \pm 0.12 \times 10^{2}, 10.4 \pm 0.52 \times 10^{2}$, and $18.1 \pm 0.91 \times 10^{2} \mathrm{mg} / \mathrm{g}$, respectively. Many authors have also affirmed the presence of these constituents in C. guianensis [20,21].

\section{Antioxidant Activity}

The percentage inhibition of the activity of 2,2-diphenyl-1-picrylhydrazyl (DPPH) was assessed as an assay of the antioxidant activity of the methanolic leaf extract of $C$. guianensis. The methanolic leaf extract of C. guianensis revealed $72.36 \%$ of inhibition at $100 \mu \mathrm{g} / \mathrm{ml}$ concentration. The percentage antioxidant activity at $10 \mu \mathrm{g} / \mathrm{ml}$ was $48 \%$, while the same at 40,60 , and $80 \mu \mathrm{g} / \mathrm{ml}$ was $55 \%, 59 \%$, and $61 \%$, respectively. Researchers relate the high phenolic content of the extract to the increased antioxidant activity. Studies on an ethanol extract of leaves of $C$. guianensis revealed effective concentration-dependent scavenging activity on DPPH [22]. Similar results have been reported by Vetrichelvan et al., Bender et al., Sincy et al., Hanamura et al. [23-26]. Powerful antioxidant activities have been reported in the methanolic leaf extracts of Dypsis leptocheilos [27] and in the aqueous extract of Oldenlandia corymbosa [28] also. A number of authors evaluated the anti-oxidative and anti-diabetic properties of green tea mixture and leaves of Pluchea plant [29-32]. They have reported the presence of $\alpha$ glucosidase inhibitory activity and $\alpha$ amylase inhibitory activity. Survey of literature revealed a number of potentials catechins present in green tea that exhibited antioxidant and prebiotic activities [30], antidiabetic [31], and analgesic effects [33].

\section{Alpha Amylase and Alpha-glucosidase Inhibitory Activity}

Methanolic leaf extract of C. guianensis at various concentrations (20, $40,60,80$, and $100 \mathrm{mg} / \mathrm{ml}$ ) showed efficient $\alpha$-amylase inhibitory activity. Researchers have suggested the $\alpha$-amylase inhibitory activity to be associated with the presence of saponin, stigmasterol, and
Table 1: Phytochemical constituents in methanolic extract of leaves of $C$.guianensis

\begin{tabular}{ll}
\hline Phytochemical & Methanolic extract of leaves of \\
constituents & C. guianensis \\
\hline Tannin & +++ \\
Phlobatannins & - \\
Saponin & +++ \\
Flavonoid & + \\
Steroids & +++ \\
Terpenoids & +++ \\
Cardiac glycosides & - \\
Leucoanthocyanin & +++ \\
Anthocyanin & +++ \\
Anthraquinone & - \\
Protein & - \\
Coumarins & + \\
Glycosides & +++ \\
Phenol & +++ \\
Alkaloids & +++ \\
Xanthoproteins & + \\
Emodin & + \\
Carbohydrates & +++ \\
\hline
\end{tabular}

C. guianensis: Couroupita guianensis

Table 2: Quantitative analysis of methanolic extract of leaves of C. guianensis

\begin{tabular}{ll}
\hline Phytochemical constituents & Mean \pm SD (mg/100 g) \\
\hline Flavonoid & $30.4 \pm 1.52 \times 10^{2}$ \\
Tannin & $10.4 \pm 0.52 \times 10^{2}$ \\
Saponin & $18.1 \pm 0.91 \times 10^{2}$ \\
Alkaloid & $2.4 \pm 0.12 \times 10^{2}$ \\
Phenol & $1.1 \pm 0.06 \times 10^{2}$ \\
Terpenoid & $1.7 \pm 0.09 \times 10^{2}$ \\
\hline
\end{tabular}

SD: Standard deviation; C. guianensis: Couroupita guianensis

lupol [23-25,34,35]. The percentage of alpha-glucosidase inhibitory activity in the methanolic leaf extracts at a concentration between 20 and $100 \mu \mathrm{g} / \mathrm{ml}$ revealed an effect between 33.33\% and 80.70\%. Researchers have affirmed the methanol extract of Tinospora sinensis to possess maximum $\alpha$-amylase inhibitory activity when compared to their ethanolic extract [26]. A number of authors have suggested that polyphenol and flavonoid have the ability to inhibit intestinal alpha-glucosidase and pancreatic alpha-amylase [36,37]. Bioactive constituents such as tannins, phenols, alkaloids, saponins, steroids, and flavonoids isolated from the extract of Croton bonplandianum have been reported to have efficient $\alpha$-amylase inhibitory activity [22]. The presence of antioxidant and $\alpha$-amylase inhibitory activity in Phyllanthus indofischeri extract is suggestive of their use as a natural antioxidant and hypoglycemic agent [38].

\section{Antimicrobicidal Activity}

Antibacterial activity of the crude methanolic leaf extract of $C$. guianensis at a concentration of $100 \mu \mathrm{g} / \mathrm{ml}$ produced zone of inhibitions of $7 \mathrm{~mm}$, $6 \mathrm{~mm}$, and $7 \mathrm{~mm}$ against Escherichia coli, Staphylococcus aureus, and Enterobacter aerogenes, respectively (Plate 1). The methanolic extract exhibited inhibitory actions against pathogens at concentrations of 60,80 , and $100 \mathrm{mg} / \mathrm{ml}$ than at lower concentrations (Table 3). As the concentration of extracts increased from 20 to $100 \mathrm{mg} / \mathrm{ml}$, the inhibitory actions of the plant extracts increased toward all the strains used in this test. However, a significant antibacterial effect could not be attributed to the extract used in the present study.

The antifungal susceptibility test of the plant extracts, against the test organisms, indicated that the methanolic extracts posed no impact on Candida albicans and Candida tropicalis (Table 4). There was no zone of inhibition developed for the two tested organisms against 


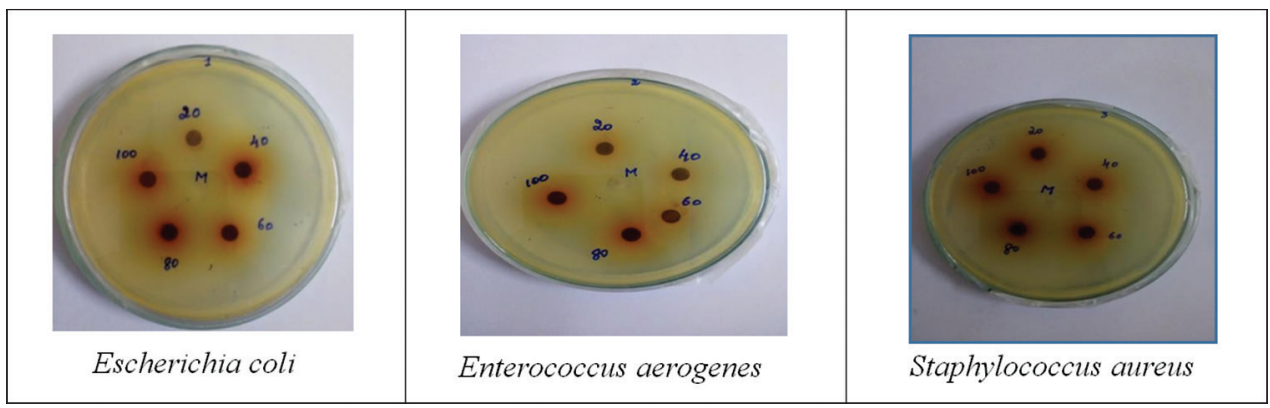

Plate 1: Photographic image of the antibacterial activity of the methanolic leaf extract of Couroupita guianensis against the three chosen bacterial strains

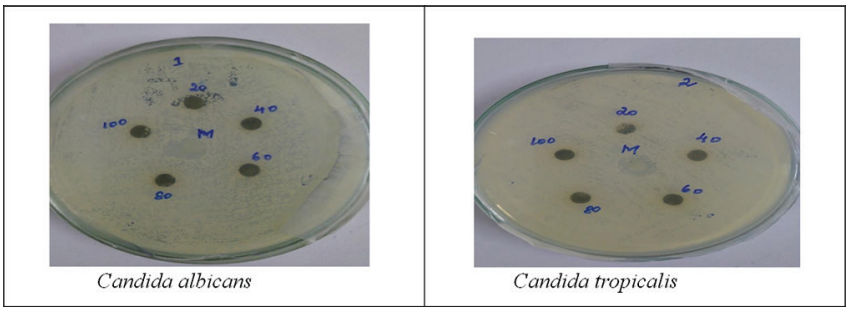

Plate 2: Photographic image of the antifungal activity of the methanolic leaf extract of Couroupita guianensis against the two chosen fungal strains

Table 3: Antibacterial activity of leaves of $C$. guianensis

\begin{tabular}{|c|c|c|c|}
\hline \multirow{2}{*}{$\begin{array}{l}\text { Concentration of } \\
\text { extract }(\mu \mathrm{g} / \mathrm{ml})\end{array}$} & \multicolumn{3}{|c|}{ Diameter of zone of inhibition ( $\mathrm{mm}$ ) } \\
\hline & $\begin{array}{l}\text { E. coli } \\
(\mathrm{mm})\end{array}$ & $\begin{array}{l}\text { S. aureus } \\
(\mathrm{mm})\end{array}$ & $\begin{array}{l}\text { E. aerogenes } \\
(\mathrm{mm})\end{array}$ \\
\hline 20 & 0 & 2 & 5 \\
\hline 40 & 4 & 3 & 6 \\
\hline 60 & 5 & 4 & 7 \\
\hline 80 & 6 & 5 & 6 \\
\hline 100 & 7 & 6 & 7 \\
\hline $10 \mu \mathrm{l} /$ disc & 0 & 0 & 0 \\
\hline
\end{tabular}

C. guianensis: Couroupita guianensis; E. coli: Escherichia coli, S. aureus: Staphylococcus aureus; E. aerogenes: Enterobacter aerogenes

Table 4: Antifungal activity of methanolic leaf extracts of C. guianensis

\begin{tabular}{lll}
\hline $\begin{array}{l}\text { Concentrations } \\
(\boldsymbol{\mu g} / \mathbf{m l})\end{array}$ & \multicolumn{2}{l}{ Diameter of the zone of inhibition $(\mathbf{m m})$} \\
\cline { 2 - 3 } & Candida albicans & Candida tropicalis \\
\hline 20 & 0 & 0 \\
40 & 0 & 0 \\
60 & 0 & 0 \\
80 & 0 & 0 \\
100 & 0 & 0 \\
$10 \mu \mathrm{l} /$ disc & 0 & 2 \\
\hline
\end{tabular}

C. guianensis: Couroupita guianensis

the methanolic extracts of $C$. guianensis (Plate 2). Survey of literature revealed that flavonoids possess antioxidant properties and give protection against allergies, ulcers, inflammation, platelet aggregation, microbes, hepatotoxins tumors, and viruses [19]. In the present study, significant antifungal activity was not established.

\section{CONCLUSIONS}

Methanolic leaf extracts of $C$. guianensis showed significant enzyme inhibitory activity, antioxidant, and antibacterial activities. However, further research on the isolation of the active phytoconstituents with therapeutic activity and clinical study for the evaluation of safety and efficacy of the drug needs to be assessed.

\section{ACKNOWLEDGMENT}

The authors would like to acknowledge the Department of Science and Technology for the FIST facility which has helped in the conduct of this research work at Holy Cross College (Autonomous), Tiruchirappalli.

\section{AUTHORS' CONTRIBUTIONS}

Research guidance - Dr. Sujatha Ilangovan, experimental work and manuscript writing - P. Thavasumani, and editing and proof correction - Dr. Sujatha Ilangovan.

\section{CONFLICTS OF INTEREST}

The authors declare no conflicts of interest.

\section{FUNDING}

Nil.

\section{REFERENCES}

1. Gerich JE. The genetic basis of type 2 diabetes mellitus: Impaired insulin secretion versus impaired insulin sensitivity. Endocr Rev 1998;19:491-503.

2. Altschuld RA, Kruger FA. Inhibition of hepatic gluconeogenesis in guinea pig by phenformin. Ann N Y Acad Sci 1968;148:612-22.

3. Deshmuch CD, Jain A. Diabetes mellitus: A review. Int J Pure Appl Biosci 2015;3:224-30.

4. Lalau JD, Lacroix C, Compagnon P, De Cagny B. Role of metformin accumulation in metformin-associated lactic acidosis. Diabetes Care 1995; 18:779-84.

5. Swapnalatha S, Rajeswari V. Antidiabetic activity of Couroupita guianensis-a review. IOSR J Pharm Biol Sci 2014;9:41-3.

6. Manimegalai S, Rakkimuthu G. Phytochemical screening of stem of Couroupita guianesis. Int J Pharm Sci Res 2012;3:4434-7.

7. Praveen KP, Kumaravel S, Lalitha C. Screening of antioxidant activity, total phenolics and GC-MS study of Vitex negundo. Afr J Biochem Res 2010;4:191-5.

8. Sofowora A. Medicinal Plants and Traditional Medicine in Africa. Ibadan, Nigeria: Spectrum Books Ltd.; 1993. p. 289.

9. Trease GE, Evans WC. Pharmacognosy. $11^{\text {th }}$ ed. London: Bailliere Tindall; 1989. p. 45-50.

10. Harborne JB. Phytochemcial Methods. London: Chapman and Hall Ltd.; 1973. p. 49-188.

11. Braca A, Sortino C, Politi M. Antioxidant activity of flavonoids from Licania licaniaeflora. J Ethnopharmacol 2002;79:379-81.

12. McCue, PP, Shetty K. Inhibitory effects of rosmarinic acid extracts on porcine pancreatic amylase in vitro. Asia Pac J Clin Nutr 2004;13:101-6.

13. Kim YM, Jeong YK, Wang MH, Lee YH, Rhee HI. Inhibitory effect of pine extract on alpha-glucosidase activity and postprandial hyperglycemia. Nutrition 2005;21:756-61.

14. Kujur RS, Singh V, Ram M, Yadava HN, Singh KK, Kumari S, et al. Antidiabetic activity and phytochemical screening of crude extract of Stevia rebaudiana in alloxan-induced diabetic rats. Pharmacogn Res 2010;2:258-63. 
15. Ramkumar KM, Rajaguru P, Ananthan R. Antimicrobial properties and phytochemical constituents of an antidiabetic plant Gymnema montanum. Adv Biol Res 2007;1:67-71.

16. Saidu AN, Mann A, Onuegbu CD. Phytochemical screening and hypoglycemic effect of aqueous Blighia sapida root bark extract on normoglycemic albino rats. Br J Pharm Res 2012;2:89-97.

17. Gauresh S, Rahul C, Jayant S, Sadhana S. Inhibition of carbohydrate hydrolysing enzymes by methanolic extract of Couroupita guianensis leaves. Int J Pharm Bio Sci 2012;3:511-20.

18. Rajalakshmi M, Ludas A, Indu S, Hinduja S. Anti-cancer potential of polysaccharide isolated from methanolic extract of Tinospora cordifolia stem bark. Int J Pharm Pharm Sci 2019;11:3-4.

19. Manimegalai S, Sridharan TB, Rameshpathy M, Rajeswari VD. Antioxidant, phytochemical screening and antimicrobial activity of Couroupita guianensis flower extract. Der Pharm Lett 2014;6:251-6.

20. Massiot G, Chen X, Lavaud C, Men-Olivier LL, Delaude C, Viari A, et al. Saponins from stem bark of Petersianthus macrocarpus. Phytochemistry 1992;31:3571-6.

21. Crublet ML, Long C, Sévenet T, Hadi HA, Lavaud C. Acylated flavonol glycosides from leaves of Planchonia grandis. Phytochemistry 2003;64:589-94.

22. Keerthana G, Kalaivani MK, Sumathy A. In-vitro alpha amylase inhibitory and anti-oxidant activities of ethanolic leaf extract of Croton bonplandianum. Asian J Pharm Clin Res 2013;6:32-6.

23. Vetrichelvan T, Jegadeesan M, Devi BA. Anti-diabetic activity of alcoholic extract of Celosia argentea Linn. seeds in rats. Biol Pharm Bull 2002;25:526-8

24. Bender D, Botham KM, Kennelly PJ. Harper's Illustrated Biochemistry. $29^{\text {th }}$ ed. New York: McGraw-Hill Professional; 2012.

25. Sincy J, Lekha K, Narmatha BV. Evaluation of anti-diabetic activity of Strobilanthes cuspidata in alloxan induced diabetic rats and the effect of bioactive compounds on inhibition of $\alpha$-amylase enzyme. $J$ Pharmacogn Phytochem 2016;5:169-75.

26. Hanamura T, Hagiwara T, Kawagishi H. Structural and functional characterization of polyphenols isolated from acerola (Malpighia emarginata DC.) fruit. Biosci Biotechnol Biochem 2005;69:280-6.

27. Ibrahim HA, Elsharawy FS, Elhassab M, Shabana S, Haggag EG. Phytochemical screening and biological evaluation of Dypsis leptocheilos leaves extract and molecular docking study of the isolated compounds. Int J Pharm Pharm Sci 2020;12:106-13.

28. Iqbal M, Shah MD, Elwon CA. Hypoglycemic and hypolipidemic effects of Oldenlandia corymbosa against alloxan induced diabetes mellitus in rats. Int J Pharm Pharm Sci 2020;12:34-40.

29. Srisook K, Buapool D, Boonbai R, Simmasut P, Charoensuk Y, Srisook E. Antioxidant and anti-inflammatory activities of hot water extract from Pluchea indica Less. herbal tea. J Med Plants Res 2012;6:4077-81.

30. Molan AL, Flanagan J, Wei W, Moughan PJ. Selenium-containing green tea has higher antioxidant and prebiotic activities than regular green tea. J Food Chem 2009;114:829-35.

31. Miura T, Koike T, Ishida T. Antidiabetic activity of green tea (Thea Sinensis L.) in genetically type 2 diabetic mice. J Health Sci 2005;51:708-10.

32. Widyawati PS, Budianta TD, Utomo AR, Harianto I. The physicochemical and antioxidant properties of Pluchea indica Less drink in tea bag packaging. Int J Food Nutr Sci 2016;5:113-20.

33. Mota MA, Landim JS, Targino TS, Da Silva SF, Da Silva SL, Pereira MR. Evaluation of the anti-inflammatory and analgesic effects of green tea (Camellia sinensis) in mice. Acta Cir Bras 2015;30:242-6.

34. Saha D, Ghosh SK, Das T, Rahman H. Effect of Adiantum caudatum in streptozotocin induced diabetes mellitus in rats. Int Res J Pharm Appl Sci 2011;1:9-15.

35. Ghule S, Prakash T, Kotresha D, Karki R, Surendra V, Goli D. Antidiabetic activity of Celosia argentea root in streptozotocin-induced diabetic rats. Int J Green Pharm 2010;4:6-11.

36. Ramkumar KM, Thayumanavan B, Palvannan T, Rajaguru P. Inhibitory effect of Gymnema montanum leaves on $\alpha$-glucosidase activity and $\alpha$-amylase activity and their relationship with polyphenolic content. Med Chem Res 2010;19:948-61.

37. Manikandan R, Vijaya Anand A, Muthumani GD. Phytochemical and in vitro anti-diabetic activity of ethanolic extract of Psidium guajava leaves. Int J Curr Microbiol Appl Sci 2013;2:15-9.

38. Kalpana S, Ramakrushna B, Anitha S. Evaluation of In vitro antioxidant ant $\alpha$-amylase inhibitory activity of Phyllanthus indoflscheri Bennet. Int J Pharm Pharm Sci 2016;8:131-6. 